\title{
Kritikus infrastruktúra-védelmi nemzetközi konferencia a Bánki karon
}

A z ICCECIP 2019 - International Conference on Central European Critical Infrastructure Protection - Közep-európai kritikus infrastruktúra-védelem Nemzetközi Konferenciának otthont adó Óbudai Egyetem Bánki Donát Gépész és Biztonságtechnikai Mérnöki Kar kutatási és képzési tevékenysége közvetlenül csatlakozik a rendezvény programjához, hiszen Magyarországon egyedül ebben az intézményben folyik biztonságtechnikai mérnökök képzése alap és mester szakon. Emellett szakirányú továbbképzés keretében először indult ezen a karon információbiztonsági szakmérnök- és robbantástechnikai szakmérnökképzés, illetve PhD-képzés - egyedülálló módon, civil egyetemként katonai műszaki tudományterületet lefedve a kritikus infrastruktúra-védelem teljes spektrumát, így a fizikai, és kiberbiztonság, a polgári védelem, a politikai biztonság területét.

1. ábra. Prof dr. Maróth Miklós az az Eötvös Lóránd Kutatási Hálózat elnöke, prof. dr. Rajnai Zoltán az ÓE Bánki Donát Kar dékánja és prof. dr. Kovács László dandártábornok a Magyar Honvédség kibervédelmi szemlélője az ICCECIP konferencián

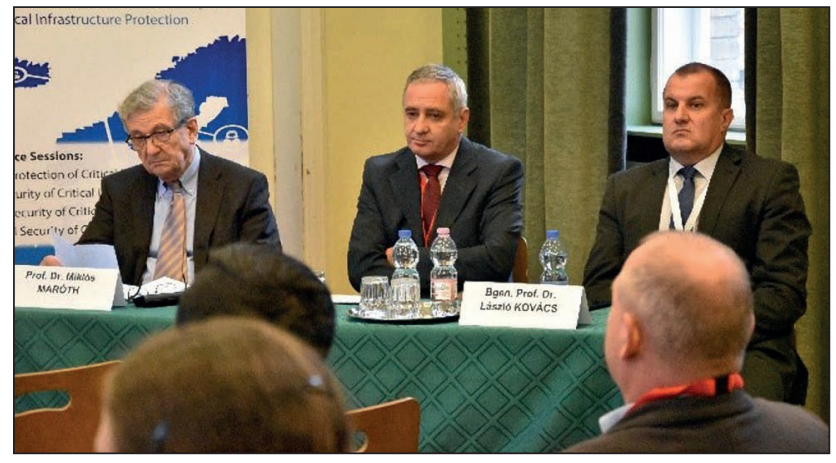

ÖSSZEFOGLALÁS: A Magyar Tudomány Ünnepe rendezvénysorozat részeként, november 18-19-én az Óbudai Egyetem Bánki Donát Gépész és Biztonságtechnikai Mérnöki Kara adott otthont az ICCECIP 2019 (International Conference on Central European Critical Infrastructure Protection) címú nemzetközi tudományos konferenciának és workshopnak. A tudományos konferencia előadásai a kritikus infrastruktúra-védelem összes területét, így a fizikai és kiberbiztonságot, a polgári védelmet, illetve a politikai biztonság témaköreit is érintették, egyes előadók kitértek a katonai-müszaki tudományok területére is.

KULCSSZAVAK: ICCECIP, kritikus infrastruktúra, ÓE, tudományos konferencia

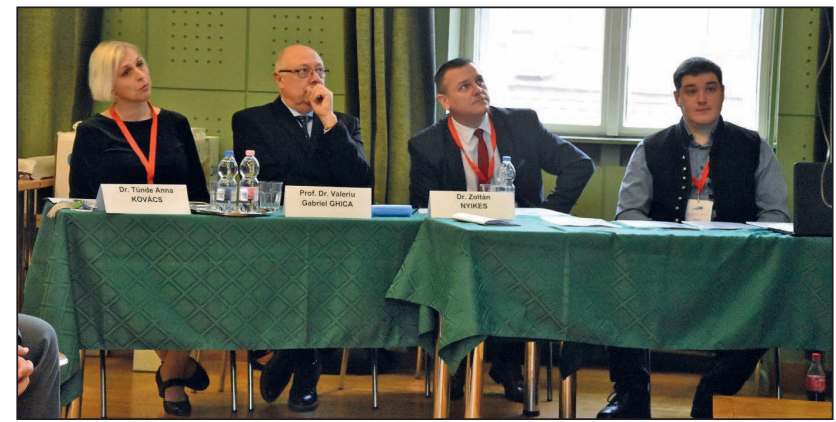

2. ábra. Az ICCECIP konferencia szervezői: dr. Kovács Tünde Anna tanszékvezető és középen dr. Nyikes Zoltán - nemzetközi résztvevők körében

A kar kutatási programjában is jelentős szerepet tölt be a kritikus infrastruktúra kutatása, így pl. a fizikai védelem területén a robbanással és lövedékekkel szemben magas ellenálló képességű kompozitok kutatása; a vészhelyzet esetén azonnal alkalmazható mobil kórházak, illetve segélyhelyek fejlesztése, vagy a kiberbiztonság területén alkalmazható új módszerek. A fizikai védelem fejlesztése igen fontos területe a kritikus infrastruktúra védelemnek, amely a nagy terheléseknek kitett berendezések elemeit is magában foglalja. Ilyen fontos eljárás a kopásnak kitett alkatrészek, szerszámok vagy orvosi eszközök felületkezelése, bevonattal történő ellátása. A kar ezen a területen nemzetközi projektekben részt vállalva jelentős kutatási eredményeket tudhat magáénak. Az ipari fejlődés és a villamos hajtású autonóm rendszerek egyre szélesebb körben való elterjedése a speciális technológiák fejlődését is eredményezi. A Bánki karon olyan hegesztéstechnológiai tudásbázis halmozódott fel az elmúlt évtizedekben, amely képes a mai kor speciális kihívásainak is eleget tenni. Ult-

ABSTRACT: The international scientific conference and workshop ICCECIP 2019 on Central European Critical Infrastructure Protection was held on 18-19 November 2019 at the Donát Bánki Faculty of Mechanical and Security Engineering of Óbuda University as part of round of events of the Festival of Hungarian Science. The scientific conference covered the entire spectrum of critical infrastructure protection, including physical and cyber security, civil defence, and political security, and in some of its presentations touched upon the field of military-technical science.

KEY WORDS: ICCECIP, Critical Infrastructure, Óbuda University, scientific conference

\footnotetext{
* Óbudai Egyetem, Bánki Donát Gépész és Bizotnságtechnikai Mérnöki Kar. ORCID: 0000-0002-3295-850X

** Óbudai Egyetem, Bánki Donát Gépész és Bizotnságtechnikai Mérnöki Kar. ORCID: 0000-0001-5654-5120

*** Óbudai Egyetem, Bánki Donát Gépész és Bizotnságtechnikai Mérnöki Kar, Anyagtudományi Intézeti Tanszék, tanszékvezető.

ORCID: 0000-0002-5867-5882
} 


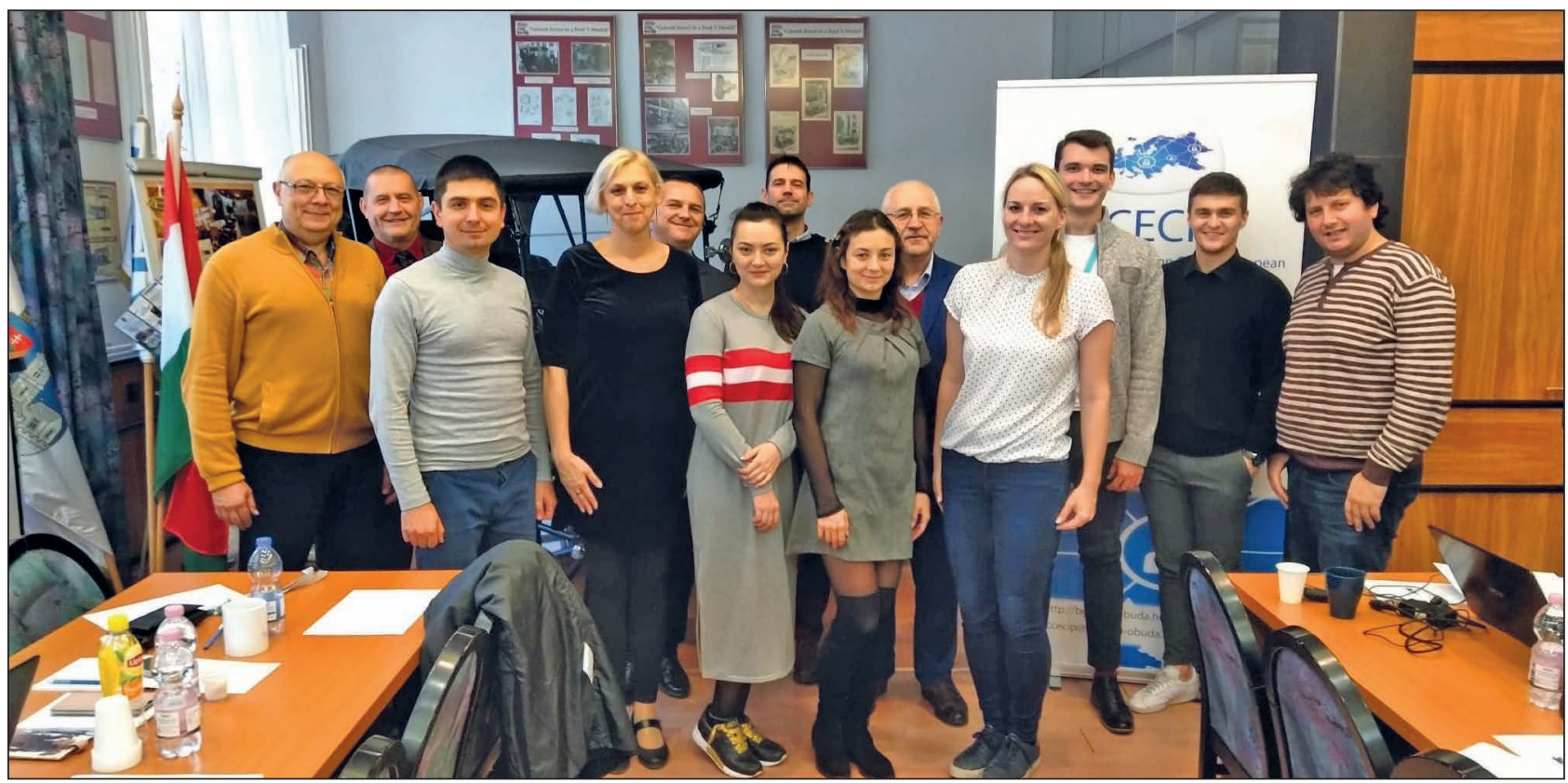

3. ábra. Az ICCECIP 2019 konferencia workshop résztvevői

rahangos hegesztési eljárással az elektronikai egységek vékony, könnyüfém burkolatai esetén is létrehozható a fémes kapcsolat a burkolaton belül található érzékeny elektronikai egységek károsodása nélkül.

A Bánki kar, valamint a V4 országok (Csehország, Lengyelország, Magyarország és Szlovákia) partner egyetemeivel évek óra tartó kiváló együttműködés és több közös tudományos kutatás eredményeként rendezték meg az ICCECIP 2019 konferenciát, amelynek fővédnöke Németh Szilárd honvédelmi miniszter-helyettes, parlamenti államtitkár volt. A szervezők mellett francia, ukrán, román, vietnámi, izraeli, szlovén és szerb résztvevők is bemutatták a kritikus infrastruktúra-védelem és a biztonságtudomány területén elért kutatási eredményeiket. A 13 ország tudományos kutatóit felvonultató nemzetközi konferenciát prof. dr. Maróth Miklós, az Eötvös Lóránd Kutatási Hálózat elnöke, valamint prof. dr. Kovács László dandártábornok, a Magyar Honvédség Parancsnokság kibervédelmi szemlélője és prof. dr. Rajnai Zoltán, a kar dékánja és Magyarország kiberkoordinátora nyitott meg. A plenáris ülésen nyolc előadás hangzott el francia, izraeli, lengyel, cseh, vietnámi, szlovén, szlo-

4. ábra. Négyen a résztvevők közül (balról jobbra): lonut Bratosin, doktorandusz (Románia), prof. dr. Valeriu Gabriel Ghica, egyetemi professzor (Románia), dr. Kovács Tünde Anna docens (ÓE) és dr. Tóth László adjunktus (ÓE)

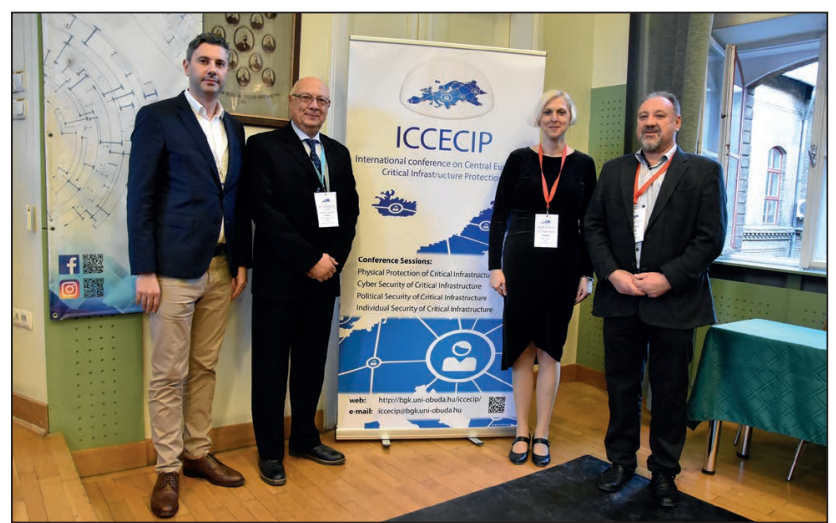

vák és magyar előadóktól, amelyeket szekcióülések követtek. Az öt szekció során 28 előadás hangzott el a kritikus infrastruktúra témaköréből. A konferencia előadásai jó lehetőséget adtak a külföldi és hazai kutatók és doktoranduszok bemutatkozására.

A tudományos konferencia egyes előadásaiban érintette a katonai-műszaki tudományok területét is, az ebben a tárgykörben elhangzott angol nyelvű előadások a Haditechnika folyóirat következő számaiban jelennek meg. A Haditechnika folyóirat önálló standdal vett részt a konferencián.

A „Tudománnyal a fejlődésért és a békéért” jelmondatú konferencia programjában, a fentiekben kiemelt témakörök mellett teret kapott a kritikus infrastruktúra minden olyan létfontosságú eleme, amely a napi létszükségletek biztosításához elengedhetetlen, pl. ivóvíz-, élelmiszer-ellátás, egészségügyi szolgáltatás, energia és szállítás biztonsága mellett a kiberbiztonságot is érinti. A program során a hallgatóság megismerhette a katonai és terrortámadás elleni védekezés módszereit, a természeti katasztrófák okozta káresetek megelőzésének lehetőségeit, illetve a bekövetkezésük esetén a kárenyhítési módokat összegző előadásokat.

A második napon a szervezők workshop-ot rendeztek és a résztvevő külföldi egyetemekkel az együttműködés lehetőségeiről tárgyaltak. A workshop moderátora dr. Leopold Kruszka volt Lengyelországból. A Szabadkai Műszaki Főiskola igazgatója, dr. Igor Fürstner, a főiskola részvételével megvalósuló Erasmus + projektet mutatta be, majd más pályázatokról egyeztettek az együttműködés keretében. A konferencia és a workshop hozzájárul a térség hasonló történelmi és kulturális múltú országainak biztonságához, a kritikus infrastruktúrák problémamentes üzemeltetéséhez, a védelmi képesség közös fejlesztéséhez, biztosítva a térség országainak jövőbeni együttműködését.

Természetesen a szervezők gondoskodnak a nagysikerű szakmai rendezvény folytatásról és a cikk megjelenésének idején már megkezdték az ICCECIP 2020 konferencia szervezését. Az idei nemzetközi kritikus infrastruktúra-védelmi konferenciát november 16-17-én rendezik az Óbudai Egyetem Bánki karán. A rendezvényre örömmel várják a szakterület területén előadni, publikálni vágyó kutatók, valamint az érdeklődők jelentkezését. 